\title{
BIAYA MUTU PENDIDIKAN
}

\author{
A. Qomarudin \\ Dosen STAI Ma'had Aly Al-Hikam Malang \\ masqomarudinyes@gmail.com
}

\begin{abstract}
Abstrak
Biaya mutu (kualitas) merupakan kajian dalam perusahaan yang konsen pada bidang bisnis, tetapi kemudian instansi yang menawarkan jasa mengadopsi beberapa manajemen yang sudah lama dipakai pada produk barang dan termasuk salah satunya adalah biaya mutu. Pendidikan merupakan golongan perusahaan/instansi yang menawarkan jasa, maka lembaga pendidikan adalah salah satu instansi yang perlu mengadopsi hal-hal terkait strategi pengelolaan pada perusahaan/instansi produk barang, tetapi pelaksanaannya harus disesuaikan dengan bidang pendidikan itu sendiri. Biaya mutu dilakukan dengan tujuan untuk mencapai penataan dan pengelolaan instansi secara baik yang disesuaikan dengan manajemennya agar terpenuhinya kepuasan konsumen/pelanggan (baik pelanggan internal maupun eksternal).

Kata kunci: biaya, mutu pendidikan
\end{abstract}

\section{A. Pendahuluan}

Bidang pendidikan sebagai salah satu fenomena kehidupan sangat erat kaitannya dengan bidang-bidang lainnya, seperti politik, ekonomi, hukum, sosial, dan budaya. Hubungan fungsional antara pendidikan dengan faktor eksternal itu demikian eratnya, sehingga faktor eksternal seharusnya menjadi sumber aspirasi yang paling utama dalam melaksanakan perubahan dan pembaharuan sistem pendidikan. Dengan kata lain, berjalannya suatu sistem pendidikan tidak dapat terlepas dari perubahan-perubahan yang terjadi dalam berbagai bidang kehidupan yang lain.

Demikian misalnya, bidang ekonomi tidak dipertentangkan dengan pendidikan oleh para ahli, tetapi justru pendidikan dipandang sebagai sumber daya kemajuan ekonomi suatu masyarakat, begitu juga sebaliknya, kemajuan bidang pendidikan memerlukan dukungan ekonomi yang kuat. Maka faktor biaya memegang peranan yang sangat penting dalam 
pembangunan pendidikan. Penyadaran akan pentingnya biaya pendidikan itu tidak saja dirasakan pada saat presiden atau pemerintah menetapkan besarnya biaya pembangunan pendidikan pada setiap tahun dalam APBN, tetapi sebenarnya pemikiran-pemikiran seperti itu akan muncul pada saat memikirkan bagaimana meningkatkan pembangunan bidang pendidikan, terutama yang terkait dengan masalah mutu, pemerataan, efisiensi, dan relevansi pendidikan.

Maka dapat dikatakan bahwa kuatnya keadaan ekonomi suatu negara akan berpengaruh secara langsung atau tidak langsung terhadap pengalokasian sumber biaya pendidikan maupun terhadap kebijakan yang akan diambil dan dilaksanakan oleh suatu negara dalam bidang pendidikannya. Maka biaya pendidikan merupakan faktor masukan yang sangat penting dalam rangka meningkatkan mutu pendidikan dan menjalankan fungsi pendidikan untuk meningkatkan kualitas sumber daya manusia. Sehingga dalam melakukan perbaikan atau peningkatan mutu secara terus menerus dan pencegahan kegagalan tujuan, sangat diperlukan biaya mutu. Biaya mutu yang makin menurun merupakan salah satu indikasi mutu barang atau jasa makin baik dan dapat memberi kepuasan pada pelanggan. Karena keinginan pelanggan dapat terpenuhi kebutuhannya dengan biaya yang serendah-rendahnya.

Melihat sangat pentingnya peranan biaya pendidikan dalam rangka meningkatkan mutu pendidikan di satu sisi, dan di sisi yang lain diperlukan juga mengenal dan memahami kompleksitas biaya pendidikan, maka penulis akan mengkaji beberapa hal yang berkaitan dengan biaya mutu (kualitas), di antaranya adalah Pengertian Biaya Mutu, Konsep Dasar Biaya Mutu, Pengelompokan Biaya Mutu, Perilaku dan Pandangan terhadap Biaya Mutu, Laporan Kinerja Biaya Mutu, serta Tujuan Biaya Mutu dalam Dunia Pendidikan.

\section{B. Pengertian Biaya Mutu}

Kata mutu memiliki varian definisi sebagaimana yang telah didefininisikan oleh masing-masing orang atau pihak sesuai dengan orientasi masing-masing terhadap objeknya. Seorang produsen dan konsumen akan memiliki definisi yang berbeda mengenai mutu barang/jasa. Namun satu kata yang menjadi benang merah dalam konsep mutu adalah kepuasan. Jadi barang/jasa dikatakan bermutu apabila barang/jasa tersebut dapat 
memberikan kepuasan, baik bagi konsumen/pelanggan maupun produsennya. ${ }^{1}$

Menurut Goetsch dan Davis bahwa mutu (quality) adalah suatu kondisi dinamis yang berhubungan dengan produk, jasa, manusia, proses, dan lingkungan yang memenuhi atau melebihi harapan. ${ }^{2}$ Maka hubungannya dengan sumber yang dapat mendatangkan mutu, ada beberapa sumber mutu yang biasa dijumpai yaitu:

1. Program, kebijakan, dan sikap yang melibatkan komitmen dari manajemen puncak.

2. Sistem informasi yang menekankan ketepatan, baik pada waktu maupun detail.

3. Desain produk yang menekankan keandalan dan perjanjian ekstensif produk sebelum dilepas ke pasar.

4. Kebijakan produksi dan tenaga kerja yang menekankan peralatan yang terpelihara baik, pekerja yang terlatih baik, dan penemuan penyimpangan secara cepat.

5. Manajemen vendor (penjual) yang menekankan kualitas sebagai sasaran utama. $^{3}$

Kaitannya dengan pengertian biaya mutu (quality cost) menurut Anonymous yang dikutip oleh Bambang Hariadi dalam buku Akuntansi Manajemen adalah ${ }^{4}$

"The cost of quality refer to resources spent to assure consistent customer satisfaction". (Biaya kualitas mengacu pada sumber daya yang dihabiskan untuk menjamin kepuasan pelanggan yang konsisten).

Sedangkan Blocher, Chen, dan Lin dalam bukunya Manajemen Biaya yang diterjemahkan oleh Susty Ambarriani, mendefinisikan biaya mutu sebagai berikut: $^{5}$

"Biaya mutu adalah biaya-biaya yang berkaitan dengan pencegahan, pengidentifikasian, perbaikan, dan pembetulan produk yang

\footnotetext{
${ }^{1}$ Tim Dosen Administrasi Pendidikan Universitas Pendidikan Indonesia, Manajemen Pendidikan (Bandung: Alfabeta, 2009), hlm. 293.

${ }^{2}$ H.B. Siswanto, Pengantar Manajemen (Jakarta: Bumi Aksara, 2011), Cet.VII, hlm. 195.

${ }^{3}$ Fandy Tjiptono dan Anastasia Diana, Total Quality Management (TQM)-Edisi Revisi (Yogyakarta: Andi, 2003), hlm. 34.

4 Bambang Hariadi, Akuntansi Manajemen: Suatu Sudut Pandang, (Yogyakarta: BPFE, 2002), Edisi Pertama, hlm. 387.

5 Blocher J. Edward, Kung H. Chen, Thomas W. Lin, 2000. Manajemen Biaya, Terjemahan Susty Ambarriani, (Jakarta: Salemba Empat, 2000), hlm. 220.
} 
berkualitas rendah, dan dengan opportunity cost dari hilangnya waktu produksi dan penjualan sebagai akibat rendahnya kualitas".

Dijelaskan juga bahwa biaya mutu adalah biaya yang terjadi atau mungkin akan terjadi karena kualitas yang buruk. Maka biaya mutu merupakan biaya yang berhubungan dengan penciptaan, pengidentifikasian, perbaikan, dan pencegahan kerusakan. ${ }^{6}$ Ada juga yang mengatakan bahwa biaya mutu adalah semua biaya yang ditimbulkan oleh bisnis untuk memastikan jumlah keseluruhan layanan yang disediakan bagi pelanggan sesuai dengan tuntutan mereka. ${ }^{7}$

Mengacu pada beberapa definisi tersebut di atas, dapat disimpulkan bahwa biaya mutu bukan saja merupakan sumber daya yang dikeluarkan untuk mencegah mutu produk yang buruk tetapi juga berupa biaya-biaya yang dikeluarkan karena terjadinya mutu yang buruk, sehingga hasil suatu produk akan sesuai dengan spesifikasi yang disyaratkan serta akhirnya dapat mencapai kepuasan konsumen. Jadi semua biaya yang timbul berkaitan dengan upaya mengubah produk bermutu buruk menjadi produk bermutu baik dengan tujuan pokoknya adalah kepuasan pelanggan merupakan cakupan dari biaya mutu.

\section{Konsep Dasar Biaya Mutu}

Pembiayaan mutu merupakan tolok ukur tentang keuntungan dari peningkatan mutu. Karena ide yang baik harus diukur, dibiayai, dan dievaluasi. Maka setiap proyek peningkatan harus didekati dengan harapan bahwa hal ini akan memberikan keuntungan yang dapat menutupi pembiayaannya. ${ }^{8}$ Beberapa alasan diperlukanya biaya mutu (kualitas) dalam suatu perusahaan di antaranya adalah:

1. Menkuantifikasi ukuran dari masalah kualitas dalam "bahasa uang", guna meningkatkan komunikasi antara manager menengah dan puncak.

2. Kesempatan utama untuk mengurangi biaya dapat diidentifikasi.

${ }^{6}$ M.N. Nasution, Manajemen Mutu Terpadu (Total Quality Management) (Jakarta: Ghalia Indonesia, 2001), hlm. 127.

7 Lesley Munro-Faure dan Malcolm Munro-Faire, Implementing Total Quality Management (Menerapkan Manajemen Mutu Terpadu, alih bahasa Sulasno Tjiptowardojo (Jakarta: Elex Media Komputindo, 1999) Cet.II, hlm. 31.

${ }^{8}$ Edward Sallis, Manajemen Mutu Terpadu Pendidikan, Judul Asli Total Quality Management in Education Alih Bahasa oleh Ahmad Ali Riyadi dan Fahrurrozi (Jogjakarta: IRCiSoD, 2011), Cet.II, hlm. 232. 
3. Kesempatan untuk mengurangi ketidakpuasan pelanggan dan ancaman-ancaman yang berkaitan dengan produk yang dipasarkan dapat diidentifikasi. ${ }^{9}$

Sedangkan alasan mengapa biaya mutu perlu diukur adalah karena biayabiaya tersebut besar sekali, tidak dikenal, dan dapat mempunyai dampak yang berarti terhadap profitabilitas dan kepuasan para pelangan. ${ }^{10}$

Beberapa perusahaan kelas dunia menggunakan ukuran biaya kualitas sebagai indikator keberhasilan program perbaikan kualitas yang dapat dihubungkan dengan ukuran-ukuran lain, seperti:

1. Biaya kualitas dibandingkan dengan nilai penjualan. Semakin rendah nilai ini, maka menunjukkan program perbaikan kualitas semakin sukses.

2. Biaya kualitas dibandingkan dengan keuntungan. Semakin rendah nilai ini, maka menunjukkan program perbaikan kualitas semakin sukses.

3. Biaya kualitas dibandingkan dengan harga pokok penjualan. Semakin rendahnya nilai ini maka menunjukkan semakin suksesnya program perbaikan kualitas. $^{11}$

Terkait dengan informasi biaya mutu (kualitas) ini dapat memberikan beberapa manfaat, di antaranya adalah:

1. Mengidentifikasi peluang laba (penghematan biaya dapat meningkatkan laba),

2. Mengambil keputusancapital budgeting dan keputusan investasi lainnya,

3. Menekan biaya pembelian dan biaya yang berkaiytan dengan pemasok,

4. Mengidentifikasi pemborosan dalam aktivitas yang tidak dikehendaki para pelanggan,

5. Mengidentifikasi sistem yang berlebiha,

6. Menentuka apakah biaya-biaya kualitas telah didistribusikan secara tepat,

7. Penentuan tujuan dalam anggaran dan perencanaan laba,

8. Mengidentifikasi masalah-masalah kualitas,

9. Dijadikan sebagai alat manajemen untuk ukuran perbandingan tentang hubungan masukan-keluaran,

10. Dijadikan sebagai salah satu alat analisis Pareto untuk membedakan antara vital few dan trivial many,

\footnotetext{
${ }^{9}$ M.N. Nasution, Manajemen..., hlm. 131.

${ }^{10}$ Lesley Munro-Faure dan Malcolm Munro-Faire, Implementing..., hlm. 35.

${ }^{11}$ M.N. Nasution, Manajemen..., hlm. 131.
} 
11. Dijadikan sebagai alat manajemen strategik untuk mengalokasikan sumber daya dalam perumusan dan pelaksanaan strategi,

12. Dijadikan sebagai ukuran penilaian kinerja yang objektif. ${ }^{12}$

Pada dasarnya biaya mutu dikembangkan dalam suatu perusahan barang, akan tetapi selanjutnya dipahami dan digunakan dalam perusahaan atau instansi yang menawarkan jasa. Pendidikan adalah salah satu instansi yang menawarkan produk jasa, dan menurut Edward Sallis bahwa produk berupa jasa memiliki perbedaan dengan barang. Pada produk jasa memiliki beberapa persyaratan antara lain: ${ }^{13}$

1. Kontak langsung antara pemberi dan penerima jasa.

2. Waktu merupakan elemen dari kualitas jasa, maka jasa harus tepat waktu. Hal ini adalah alat utama yang digunakan untuk menilai apakah konsumen puas atau tidak.

3. Jika terjadi cacat tidak dapat diperbaiki, karena jasaditerima langsung oleh pelanggan.

4. Tidak kasat mata, baik bentuk maupun kualitasnya. Maka dalam hal ini proses dinilai lebih utama daripada produk.

5. Sulit diukur dengan keberhasilan (output dan produktivitasnya)

6. Kepuasan yang dapat menjadi indikator.

Oleh karena itu, jasa yang diberikan oleh institusi pendidikan adalah pengajaran, penilaian atau pengujian, dan bimbingan yang diberikan kepada pelanggan eksternal ${ }^{14}$ (peserta didik, orang tua, masyarakat, sponsor, dan lain-lain).

\section{Pengelompokan Biaya Mutu}

Hubungannya dengan kategori biaya mutu, J.M. Juran adalah orang yang pertama mengelompokkan biaya mutu produk menjadi kategori berikut.

1. Biaya kegagalan ekternal, adalah biaya yang terjadi karena faktor luar organisasi perusahaan, seperti akibat ulah konsumen. Biaya ini terdiri

\footnotetext{
${ }^{12}$ Fandy Tjiptono dan Anastasia Diana, Total..., hlm. 40-41.

${ }^{13}$ Mukhamad Ilyasin dan Nanik Nurhayati, Manajemen Pendidikan Islam : Konstruksi Teoritis dan Praktis (Malang: Aditya Madia Publishing, 2012), hlm. 312-313.

${ }^{14}$ Pelanggan pendidikan dibagi menjadi dua, yaitu: 1) pelanggan internal, termasuk di dalamnya kepala sekolah, guru, dan karyawan sekolah, 2) pelanggan eksternal, di dalamnya mencakup eksternal primer (para siswa), eksternal sekunder (orang tua, para pemimpin pemerintah, dan perusahaan), dan eksternal tersier (pasar kerja dan masyarakat luas). Lihat dalam Mukhamad Ilyasin dan Nanik Nurhayati, Manajemen..., hlm. 293.
} 
dari biaya keluhan konsumen, penggantian, jaminan, ganti rugi, dan biaya nama baik. ${ }^{15}$

2. Biaya kegagalan internal, adalah biaya yang terjadi di lingkup perusahaan sebelum produk dikirimkan ke konsumen. Biaya ini terdiri dari biaya disposisi, membuangnya menjadi barang apkir (ditolak; ditampik; tidak dapat dipakai), mengerjakan kembali, tes ulang, bahan sisa, nganggur, persediaan cadangan penyelamat, lembur akibat produk rusak, dan biaya kelebihan kapasitas. ${ }^{16}$

3. Biaya penelaahan, adalah biaya yang dikeluarkan untuk menelaah atau mengamati sehingga ditemukan kondisi bahan dan produk yang cacat atau rusak. Biaya ini terdiri dari biaya pemeriksaan bahan yang datang, pemeriksaan selama proses produksi, pemeliharaan alat untuk tes, dan biaya evalusi persediaan. ${ }^{17}$

4. Biaya pencegahan, adalah biaya yang dikeluarkan sebagai upaya mencegah terjadinya kerusakan produk (biaya untuk meminimumkan biaya penelaahan). Biaya ini terdiri dari biaya perencanaan mutu, desain produk dan tinjauan ulang, mendesain proses dan tinjau ulang, desai tugas dan pelatihan, kendali proses, koleksi-analisis-laporan, dan biaya program perbaikan mutu. ${ }^{18}$

Dijelaskan juga pembagian biaya mutu menjadi biaya pasti dan biaya yang dapat dihindari. Biaya pasti adalah biaya yang diperlukan untuk mencapai dan menjaga standar kerja baku. Sedangkan biaya yang dapat dihindari adalah biaya yang muncul bila pekerjaan yang salah dikerjakan. ${ }^{19}$ Biaya yang termasuk dalam biaya pasti adalah biaya penelaahan dan biaya pencegahan, karena biaya tersebut diperlukan sebelum dan selama produksi dengan tujuan untuk mencapai dan menjaga standar kualitas sebelum akhirnya dinikmati oleh konsumen atau pelanggan. Sedangkan biaya yang termasuk dalam biaya yang bisa dihindari adalah biaya kegagalan eksternal dan internal. Karena biaya tersebut muncul setelah produk tersebut dinikmati oleh konsumen/pelanggan dan mereka merasa kecewa atas produk yang mereka pakai, dan atau metode yang digunakan tidak efektif dan tidak efisien.

${ }^{15}$ Suyadi Prawirosentono, Filosofi Baru tentang Manajemen Mutu Terpadu Abad 21 kiat membangun bisnis kompetitif (Jakarta: Bumi Aksara, 2007), Ed. 2, Cet.I, hlm. 26.

${ }^{16}$ Suyadi Prawirosentono, Filosofi Baru ..., hlm. 26-27.

${ }^{17}$ Suyadi Prawirosentono, Filosofi Baru ..., hlm. 28.

${ }^{18}$ Suyadi Prawirosentono, Filosofi Baru ..., hlm. 28-29.

19 Jerome S. Arcaro, Pendidikan Berbasis Mutu: Prinsip-prinsip Perumusan dan Tata Langkah Penerapan, Penerjemah Yosal Iriantara, Judul Asli Quality in Education: An Implementation Handbook (Yogayakarta: Pustaka Pelajar, 2006), Cet.III, hlm. 194. 


\section{E. Perilaku dan Pandangan terhadap Biaya Mutu}

Mutu dapat diukur antara lain dengan berdasarkan biaya yang dikeluarkan. Maka yang dikehendaki oleh suatu perusahaan adalah pembiayaan mutu turun, namun dapat memperoleh mutu yang lebih tinggi, setidak-tidaknya sampai dengan titik tertentu. Apabila standar kerusakan nol dapat dicapai, maka perusahaan masih harus menanggung biaya pencegahan dan penilaian/deteksi. ${ }^{20}$

Hubungannya dengan laporan kinerja mutu agar dapat bermanfaat, maka beberapa hal berikut perlu diperhatikan, yaitu:

1. Biaya kualitas harus digolongkan ke dalam biaya variabel dan biaya tetap dihubungkan dengan penjualan.

2. Untuk biaya variabel, penyempurnaan kualitas dicerminkan oleh pengurangan rasio biaya variabel.

3. Untuk biaya tetap, penyempurnaan biaya kualitas dicerminkan oleh perubahan absolut jumlah biaya tetap. ${ }^{21}$

Setelah selesai mengidentifikasi beberapa biaya mutu produk di atas, maka langkah selanjutnya bagi suatu organisasi perusahaan adalah menjabarkannya secara jelas pada setiap pendistribusiannya ke dalam masing-masing kategori biaya mutu produk. Karena kegagalan dalam menghitung biaya mutu produk dapat berarti fatal dengan muara membatalkan rencana perbaikan kualitas produk. $^{22}$ Kemudian bagaimana cara mencari data biaya perbaikan mutu produk dapat dilakukan melalui tiga cara, yaitu: 1) menelaah kembali lalu menganalisis dokumen produksi dan tugas karyawan, 2) menciptakan dan memelihara dokumen sementara yang berkaitan dengan mutu produk, dan 3) melakukan observasi secara langsung pada operasi produksi. ${ }^{23}$

Kaitannya dengan pandangan terhadap biaya mutu pada masa yang lalu banyak manajer bisnis yang beranggapan bahwa peningkatan kualitas pasti dibarengi dengan peningkatan biaya, sehingga sampai pada anggapan kualitas yang lebih tinggi berarti memerlukan biaya yang lebih tinggi pula. Pandangan seperti ini dipertanyakan oleh para pioner kualitas, sehingga Juran meneliti aspek ekonomis dari kualitas dan menyimpulkan bahwa manfaat kualitas jauh melebihi biayanya. Feigenbaum memperkenalkan total quality control dan mengembangkan prinsip bahwa kualitas merupakan

\footnotetext{
${ }^{20}$ M.N. Nasution, Manajemen..., hlm. 132.

${ }^{21}$ M.N. Nasution, Manajemen..., hlm. 132.

${ }^{22}$ Suyadi Prawirosentono, Filosofi Baru ..., hlm. 29-30.

${ }^{23}$ Suyadi Prawirosentono, Filosofi Baru ..., hlm. 32. 
tanggung jawab setiap orang. Sedangkan Crosby mengajukan konsepnya yang terkenal dengan quality is free, maksudnya produk tidak boleh ada yang cacat atau rusak. Dewasa ini ada tiga kategori yang berkembang di antara praktisi terkait dengan biaya kualitas, yaitu:

1. Kualitas yang makin tinggi berarti biaya yang makin tinggi pula. Jadi manfaat tambahan dari peningkatan kualitas tidak dapat menutupi biaya tambahan.

2. Biaya peningkatan kualitas lebih rendah daripada penghematan yang dihasilkan. Jadi penghematan dihasilkan dari berkurangnya tingkat pengerjaan ulang, produk cacat, dan biaya langsung yang berkaitan dengan kerusakan.

3. Biaya kualitas merupakan biaya yang besarnya melebihi biaya yang terjadi bila barang atau jasa dihasilkan secara benar sejak saat pertama produksi. Jadi biaya tidak hanya menyangkut biaya langsung, tetapi juga biaya akibat kehilangan pelanggan, kehilangan pangsa pasar, dan banyak biaya tersembunyi lainnya serta peluang yang hilang dan tidak teridentifikasi oleh sistem akutansi biaya modern. ${ }^{24}$

Menurut Juran, struktur biaya kualitas sangat dipengaruhi oleh interaksi antara keempat jenis biaya kualitas, yaitu biaya pencegahan, biaya penilaian, biaya kegagalan internal, dan biaya kegagaln eksternal. Biaya pengendalian, yaitu biaya pencegahan dan penilaian meningkat seiring dengan peningkatan kualitas, sedangkan biaya kegagalan (internal dan eksternal) menurun seiring dengan peningkatan kualitas. Hubungan ini, apabila digambarkan, akan menjadi kurva biaya kualitas total yang berbentuk huruf "U. Juran menyarankan agar manajemen dapat menemukan level atau tingkat kualitas (jumlah kerusakan ) yang tepat sehingga akan meminimumkan biaya kualitas total. ${ }^{25}$

\footnotetext{
${ }^{24}$ M.N. Nasution, Manajemen..., hlm. 132-133.

${ }^{25}$ Fandy Tjiptono dan Anastasia Diana, Total..., hlm. 44.
} 


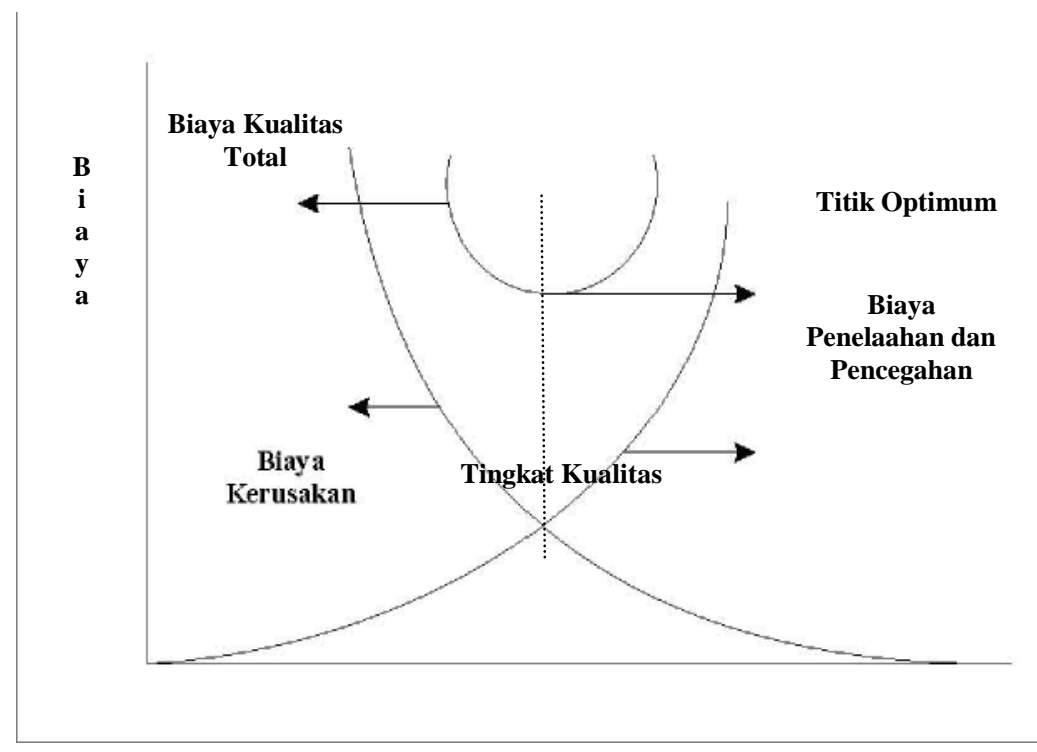

\section{F. Laporan Kinerja Biaya Mutu}

Untuk memungkinkan manajemen melakukan perencanaan, pengendalian, dan pengambilan keputusan tentang biaya kualitas, manajemen memerlukan laporan biaya kualitas secara periodik dalam bentuk perbandingan antarperiode akuntansi. Laporan kinerja ini penting untuk program perbaikan kualitas. berikut :

Empat jenis kemajuan yang dapat diukur dan dilaporkan adalah sebagai

1. Laporan standar interim, laporan kinerja mutu interim membandingkan biaya sesungguhnya untuk periode tersebut dengan yang dianggarkan. Laporan ini untuk menunjukkan kemajuan yang berkembang dengan standar atau sasaran periode sekarang.

2. Laporan trend satu periode, laporan trend satu periode membandingkan kinerja tahun ini dengan cara membandingkan biaya mutu yang sesungguhnya terjadi pada tahun ini dan biaya mutu yang sesungguhnya di tahun sebelumnya. Laporan ini untuk menunjukkan kemajuan yang berhubungan dengan kinerja kualitas tahun terakhir.

3. Laporan trend periode ganda, laporan ini untuk menunjukkan kemajuan sejak awal mula program penyempurnaan mutu sampai periode terakhir. Laporan ini biasanya disajikan dalam sebuah grafik, sumbu vertikal menggambarkan biaya mutu dalam persentase yang dihitung dari penjualan, sumbu mendatar menunjukkan tahun-tahun program penerapan mutu. 
4. Laporan jangka panjang, laporan kinerja mutu jangka panjang membandingkan biaya mutu sesungguhnya untuk periode ini dengan biaya yang diharapkan jika standar kerusakan nol tercapai dengan anggapan tingkat penjualan sama dengan tingkat penjualan periode ini. Laporan ini untuk menunjukkan kemajuan yang berhubungan dengan standar atau sasaran jangka panjang.

\section{G. Tujuan Biaya Mutu dalam Dunia Pendidikan}

Tujuan dari biaya mutu secara spesifik dalam dunia pendidikan adalah membantu manajemen (pengelola) untuk memaksimalkan proses belajar mengajar dan pelayanan yang diterima pelanggan. Jadi bila seorang peserta didik tidak dapat menyelesaikan pendidikan atau terjadi ujian ulangan, kejadian ini adalah menjadi tanggungjawab dalam biaya mutu. Mengacu pada pengelompokan biaya mutu di atas, biaya mutu dalam pendidikan dapat dijabarkan dan diklasifikasikan dalam beberapa kategori, yaitu biaya pencegahan, penilaian/penelaahan, biaya kegagalan internal dan biaya kegagalan eksternal. ${ }^{26}$

1. Biaya Pencegahan, adalah biaya-biaya yang dikeluarkan untuk meminimumkan peserta didik yang keluar sebelum selesai/lulus (dropout). Biaya pencegahan sering menjadi biaya yang tidak banyak diketahui dikeluarkan dan memberikan efek ganda terhadap penurunan penilaian dan biaya kegagalan. Biaya pencegahan diantaranya adalah: a) biaya seleksi penerimaan peserta didik, b) biaya pelatihan/kursus pengajar (SDM) maupun peserta didik, c) biaya memotivasi peserta didik, dan d) biaya pengujian ulang.

2. Biaya penilaian/penelaahan, adalah yang berhubungan dengan biayabiaya aktifitas pendidikan. Biaya penilaian diantaranya adalah: a) biaya umpan balik, dan b) biaya penilaian terhadap peserta didik yang tidak dapat menyelesaikan pendidikan.

3. Biaya kegagalan internal, adalah biaya-biaya yang terjadi hasil cacat dan kegagalan dalam lembaga, yang memberikan kontribusi kepada kegagalan peserta didik. Termasuk diantaranya adalah: a) biaya Sumber daya manusia, b) biaya yang dikeluarkan, akhirnya peserta didik gagal, c) hutang piutang peserta dididik yang gagal tidak dibayar, dan d) opportunity cost akibat kapasitas kelas diisi oleh peserta didik yang mengulang.

26 Haslizen Hoesin, Strategi Biaya Mutu Pendidikan (http://lizenhs.wordpress.com/2008/11/21/strategi-biaya-mutu-pendidikan/), Diakses pada Senin, 23 Juli 2018, 13.14 wib. 
4. Biaya kegagalan eksternal, biaya-biaya kegagalan eksternal ini sangat penting diperhatikan, karena biaya ini menggambarkan mutu yang dibawa peserta didik ke pendidikan berikutnya atau di masyarakat. Biaya kegagalan eksternal meliputi: a) peserta didik sebagai pelanggan: (1) uang pendidikan, (2) pendidikan tambahan mencapai mutu yang diharapkan, dan (3) kerugian waktu. b) lembaga pendidikan lebih lanjut: (1) tambahan pendidikan untuk menyeragamkan pengetahuan, dan (2) kerugian waktu. c) pemberi Beasiswa: (1) pemborosan bantuan yang diberikan akibat kegagalan lembaga pendidikan, dan (2) pemborosan bantuan yang diberikan kepada peserta didik yang gagal.

\section{H. Kesimpulan}

Secara umum, biaya mutu (kualitas) adalah kajian yang terdapat dalam perusahan yang konsen pada bidang bisnis atau perusahan/instansi yang menawarkan produk barang, tetapi kemudian instansi yang menawarkan jasa mengadopsi beberapa manajemen yang sudah lama dipakai pada produk barang dan termasuk salah satunya adalah biaya mutu.

Dalam hal ini pendidikan dapat dikategorikan ke dalam golongan perusahaan/instansi yang menawarkan jasa. Maka lembaga pendidikan adalah salah satu yang dirasa perlu untuk mengadopsi hal-hal terkait strategi pengelolaan pada perusahaan/instansi produk barang, tetapi pelaksanaannya disesuaikan dengan bidang pendidikan itu sendiri, yang tentunya memiliki batasan-batasan tertentu.

Tujuan utama dilakukannya hal di atas adalah untuk pencapaian tujuan instansi/lembaga dengan penataan dan pengelolaan instansi secara baik yang disesuaikan dengan pengaturannya (manajemennya). Ini menjadi penting karena lembaga pendidikan juga harus menjaga dan terus memperbaiki mutu (kualitas) bersama dalam suatu organisasi secara bertahap. Sebab kepuasan konsumen/pelanggan (baik pelanggan internal maupun eksternal) adalah menjadi prioritas tujuan utama yang harus terpenuhi.

\section{DAFTAR RUJUKAN}

Arcaro, Jerome S. 2006. Pendidikan Berbasis Mutu: Prinsip-prinsip Perumusan dan Tata Langkah Penerapan, Penerjemah Yosal Iriantara, Judul Asli Quality in Education: An Implementation Handbook. Yogayakarta: Pustaka Pelajar.

Edward, Blocher J. Kung H. Chen, Thomas W. Lin. 2000. Manajemen Biaya, Terjemahan Susty Ambarriani. Jakarta: Salemba Empat. 
Hariadi, Bambang. Akuntansi Manajemen: Suatu Sudut Pandang, (Yogyakarta: BPFE, 2002).

Hoesin, Haslizen. Strategi Biaya Mutu Pendidikan (http://lizenhs.wordpress.com/2008/11/21/strategi-biaya-mutupendidikan/).

Ilyasin, Mukhamad dan Nanik Nurhayati. 2012. Manajemen Pendidikan Islam : Konstruksi Teoritis dan Praktis. Malang: Aditya Madia Publishing.

Munro-Faure, Lesley dan Malcolm Munro-Faire. 1999. Implementing Total Quality Management (Menerapkan Manajemen Mutu Terpadu, alih bahasa Sulasno Tjiptowardojo. Jakarta: Elex Media Komputindo.

Nasution, M.N. 2001. Manajemen Mutu Terpadu (Total Quality Management). Jakarta: Ghalia Indonesia.

Prawirosentono, Suyadi. 2007. Filosofi Baru tentang Manajemen Mutu Terpadu Abad 21 kiat membangun bisnis kompetitif. Jakarta: Bumi Aksara.

Sallis, Edward. 2011. Manajemen Mutu Terpadu Pendidikan, Judul Asli Total Quality Management in Education Alih Bahasa oleh Ahmad Ali Riyadi dan Fahrurrozi. Jogjakarta: IRCiSoD.

Siswanto, H.B. 2011. Pengantar Manajemen. Jakarta: Bumi Aksara.

Tim Dosen Administrasi Pendidikan Universitas Pendidikan Indonesia. 2009. Manajemen Pendidikan. Bandung: Alfabeta.

Tjiptono, Fandy dan Anastasia Diana. 2003. Total Quality Management (TQM)-Edisi Revisi. Yogyakarta: Andi. 